\title{
Journal Club: a group of research experience
}

\author{
Clube de revistas: experiência de um grupo de pesquisa \\ Club de revistas: experiencia de un grupo de investigación científica
}

\section{Patricia Bover Draganov', Maria Regina Guimarães Silva', Vanessa Ribeiro Neves', Maria Cristina Sanna' \\ 'Universidade Federal de São Paulo, Postgraduate Program in Nursing. São Paulo, Brazil.}

How to cite this article:

Draganov PB, Silva MRG, Neves VR, Sanna MC. Journal Club: a group of research experience.

Rev Bras Enferm [Internet]. 2018;71(2):446-50. DOI: http://dx.doi.org/10.1590/0034-7167-2016-0539

Submission: 12-09-2016 Approval: 04-21-2017

\section{ABSTRACT}

Introduction: the Journal Club (JC) is a teaching and learning strategy developed by individuals who meet to discuss scientific articles in periodicals. Objective: to describe the experience of the JC strategy at the Group for Studies and Research in Health Services Administration and Nursing Management (Gepag). Method: case studies or scientific research demonstration mode of practical experience for the understanding and justification of facts. Results: Gepag JC emerged in 2008 and, in 2014, was computerized with the Google Drive ${ }^{\circledR}$, in order to increase its scope and optimize the Groupss meetings. From April to May 2014, the instrument was tested and adjusted, resulting in advancements. Final considerations: the advantages involved optimizing the time of meetings, facilitation of access to publications of interest to the Group and creating the database to support future research.

Descriptors: Learning; Graduate Education in Nursing; Information and Communications Technology; Nursing Administrators; Research in Nursing Administration.

\section{RESUMO}

Introdução: o Clube de Revistas (CR) é uma estratégia de ensino e aprendizagem desenvolvida por indivíduos que se encontram para discutir artigos científicos selecionados em periódicos. Objetivo: descrever a experiência da estratégia do CR no Grupo de Estudos e Pesquisas em Administração de Serviços de Saúde e Gerenciamento de Enfermagem (Gepag). Método: relato de experiência ou modalidade de investigação científica de demonstração de experiência prática para compreensão e fundamentação de fatos. Resultados: o CR do Gepag surgiu em 2008 e, em de 2014, foi informatizado com o Google Drive , a fim de aumentar sua abrangência e otimizar as reuniões do grupo. De abril a maio de 2014, a ferramenta foi testada e ajustada, resultando em ganhos. Considerações finais: as vantagens envolveram a otimização do tempo das reuniões, a facilitação do acesso às publicações de interesse do grupo e a criação de banco de dados para subsidiar futuras pesquisas.

Descritores: Aprendizagem; Educação de Pós-graduação em Enfermagem; Tecnologia da Informação; Enfermeiras Administradoras; Pesquisa em Administração de Enfermagem.

\section{RESUMEN}

Introducción: el Club de Revistas (CR) es una estrategia de enseñanza y aprendizaje desarrollada por individuos que se encuentran para discutir artículos científicos seleccionados en periódicos. Objetivo: describir la experiencia de la estrategia del CR en el Grupo de Estudios e Investigaciones en Administración de Servicios de Salud y Gerencia de Enfermería (Gepag). Método: se trata de un relato de experiencia o modalidad de investigación científica como demostración de experiencia práctica para la comprensión y fundamentación de los hechos. Resultados: el CR del Gepag surgió en 2008 y se informatizó con el Google Drive ${ }^{\circledR}$ en 2014 , con el fin de aumentar su alcance y optimizar las reuniones del grupo. La herramienta se probó y se ajustó de abril a mayo de 2014 , resultando en ganancias. Consideraciones finales: entre las ventajas estaban la optimización del tiempo de las reuniones, más accesibilidad a las publicaciones de interés del grupo y la creación de bancos de datos para subsidiar futuras investigaciones.

Descriptores: Aprendizaje; Educación de Posgrado en Enfermería; Tecnología de la Información; Enfermeras Administradoras; Investigación en Administración de Enfermería. 


\section{INTRODUCTION}

The Directory of Research Groups (DRG) in Brazil is a project developed by the National Council for Scientific and technological development (CNPq) since 1992 and is the activity inventory of scientific and technological research in activity in the Country ${ }^{(1)}$.

The research groups cataloged at the $\mathrm{CNPq}$ database are mainly based in universities, institutions of higher education with graduate degrees stricto sensu, scientific research institutes and technological institutes. The South and Southeast regions have more courses which will be mostly focused on health graduate courses/ programs and, consequently, have the largest number of research groups in Brazil. At Paulista Nursing School (PNS), Unifesp, there are 24 research groups registered and, among these, stands out in this report, the group of studies and research in health services administration and Nursing Management (Gepag) ${ }^{(2)}$.

Gepag began its activities in 2003 at Unifesp and it is proposed to carry out studies and research in health services administration and Nursing management in order to strengthen the set of research lines which it works with ${ }^{(3)}$. This group has adopted, since 2010, ten skills to the development of the students and researchers who are involved, namely: 1) Propose/ point research questions that can be studied; 2) Propose methods for the development of the research; 3) Plan, perform and evaluate actions of development of a research; 4) Guide/participate in the guidance of researchers in the research development; 5) to communicate research results in oral and written form; 6) Know how to select/indicate means of dissemination for research results; 7) Consume critically research reports; 8) position themselves ethically in relation to production and consumption of research reports; 9) Contribute to the research development from other researchers; and 10) position themselves politically on issues that involve the process of search work in Nursing, individually (defending their own ideas) or collective (debating with peers, proposing or leading collective actions along with the representation bodies) ${ }^{(3)}$.

In 2016, five other competencies were added: 11) seek information about ongoing movements in the fields of practice and research in health administration and Nursing; 12) learn/ use advanced technology tools to conduct research; 13) develop strategies to obtain data/instruments for a research; 14) learn the standard language to formulate projects/research issues and describe their results; and 15) Know, operate and criticize instruments to research support.

These skills must be developed in five increasing levels of comprehensiveness and depth, according to the desired degree by the member, which develops and delivers, annually, a portfolio in which they are registered. In the sixth and seventh competencies, the search and critical reading of scientific articles are introduced to PhD students, who should share and discuss publications relating to the objects of study of Gepag through the Journal Club (JC).

In this sense, the JC is a teaching and learning strategy developed by individuals who are aiming to discuss scientific articles in periodicals. The first formal evidence of this strategy date of $1875^{(4)}$ and its objective is to provide the ability for critical assessment of reading ${ }^{(5)}$, knowledge of research methods and the researcher upgrading ${ }^{(4)}$. In this way, the JC is a possible methodology of health education, permanent education and the instrumentalization to evidence-based practice and organizational change ${ }^{(5-7)}$. It is also an effective educational resource ${ }^{(8)}$, which can help to develop graduate programs, students, fundamental skills for the formation of teachers and doctors ${ }^{(5-6)}$.

According to Friedlander ${ }^{(9)}$, one of the most important intellectual skills of a researcher is to know how to interpret/judge research reports published as articles in scientific journals or developed in the form of theses or dissertations. The scientific community expects that the qualified professional is able to teach and train new researchers, undertake new research, produce science, participate in examination committees, evaluate the merit of scientific work, evaluate resumes and participate in research groups. These skills can be developed from the exercise of critical reading of inputs that are often presented in the JC.

The Health literature is constantly expanding and is increasingly diverse. Health professionals need to keep updated, and this tool is an opportunity to select studies of interest and make them critically to the research groups, since one of the functions of the JC is to stimulate discussion in the scientific literature available.

In this scenario, the present report is justified both by the scarcity of scientific literature on JCs and the possibility of contributing to the replication of this strategy of learning with research groups from other universities.

\section{OBJECTIVE}

The objective of this publication was to describe the experience of eight years with the use of JC strategy at Gepag, as well as the process and the advancements from the use of information and communication technology used for this.

\section{METHOD}

As a method, we used the case studies, which consists of a scientific research demonstration mode of practical experiences for greater understanding and reasoning of a fact. This research, named Ethnography Design, which provides a framework for the study of patterns, lifestyles and experiences of a particular cultural group of holistic mode ${ }^{(10)}$.

\section{Gepag's Journal Club Trajectory}

The JC emerged in 2008, according to the minutes of meetings numbers 44 and 45 from Gepag, with the purpose of disseminating current research interests in the areas of management of nursing services and health education. At the time, each doctoral student member of the group assumed a periodical and, according to the validity of the journal, provided information about articles of interest to the group's research lines, published in the journal, and transmitted them orally during the first hour of the monthly meetings, to all members present on this occasion.

This mode of conducting the JC was serving its purpose of sharing, updating and analyzing information, but it took part of the duration of the meetings and it often did not cover all the members of the group, considering the absence of some members. 
Therefore, in April 2014, there was the proposal to computerize the JC in order to increase its scope and optimize the Group's meetings. The transformations of this strategy, over time, can be seen in Figure 1.

To achieve the computerization of the JC, Google Drive ${ }^{\circledR}$ was used, a service of file synchronization and storage that offers several options such as documents, spreadsheets, and presentations, among others. It is based on the concept of cloud computing, whereby you can store files and access them from any computer or other compatible devices, as long as they are connected to the Internet ${ }^{(11)}$.

For three months, a form was prepared based on variables, which were from the oral information during the meetings - title of the article, the origin of the journal, descriptors, summary and criticism of the content and the name of the doctoral student in charge of the journal and other relevant information. For those wishing to read, use and/or cite the publication later, the reference in the Vancouver style was informed, Qualis ${ }^{1}$ classification of the journal, the main theme and the link to the article, as shown in Figure 2.

This new way of operating the Group was introduced in March 2014, when, as it happens every biennium, there was a redistribution of the periodicals of the JC among the 21 doctoral candidates, and they were invited to feed the page of Google Drive ${ }^{\circledR}$ with the data related to the 24 national and international nursing journals. The journals that were part of the JC can be appreciated on Chart 1.

To this end, each PhD student was instructed to open an email account on Gmail ${ }^{\circledR}$, necessary procedure so that they could have access to the form. Once included on the form, the data is migrated to a worksheet in the Microsoft Excel ${ }^{\circledR}$, in which information about all publications were compiled, offering these researchers a panorama of all the material selected and read.

During the months of April and May, 2014, PhD candidates tested the instrument and proposed adjustments to the items that composed the worksheet, as regards to the journal Qualis classification and the inclusion of the link to access the article, in order to minimize possible failures in the process. Such adjustments have been carried out and, from July 2014, Gepag's JC became computerized. The PhD students started feeding the datasheet constantly, the information was made available to all members of the group, and the researchers responsible for this

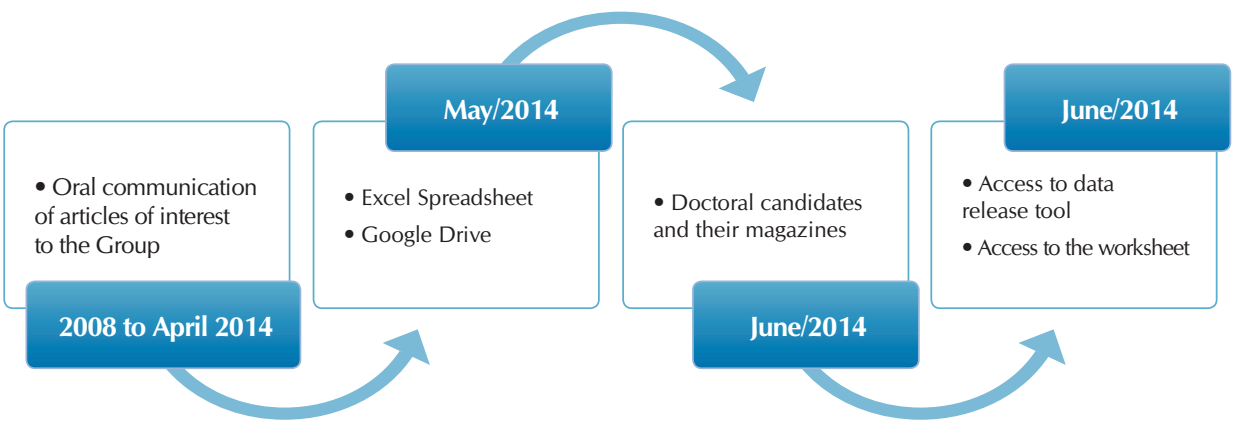

Figure 1 - Changes occurred in the Journal Club during the period from 2008 to 2014 initiative have brief bulletins on the JC at the beginning of each meeting, to solve possible doubts and promote consultation and the use of such information by their peers.

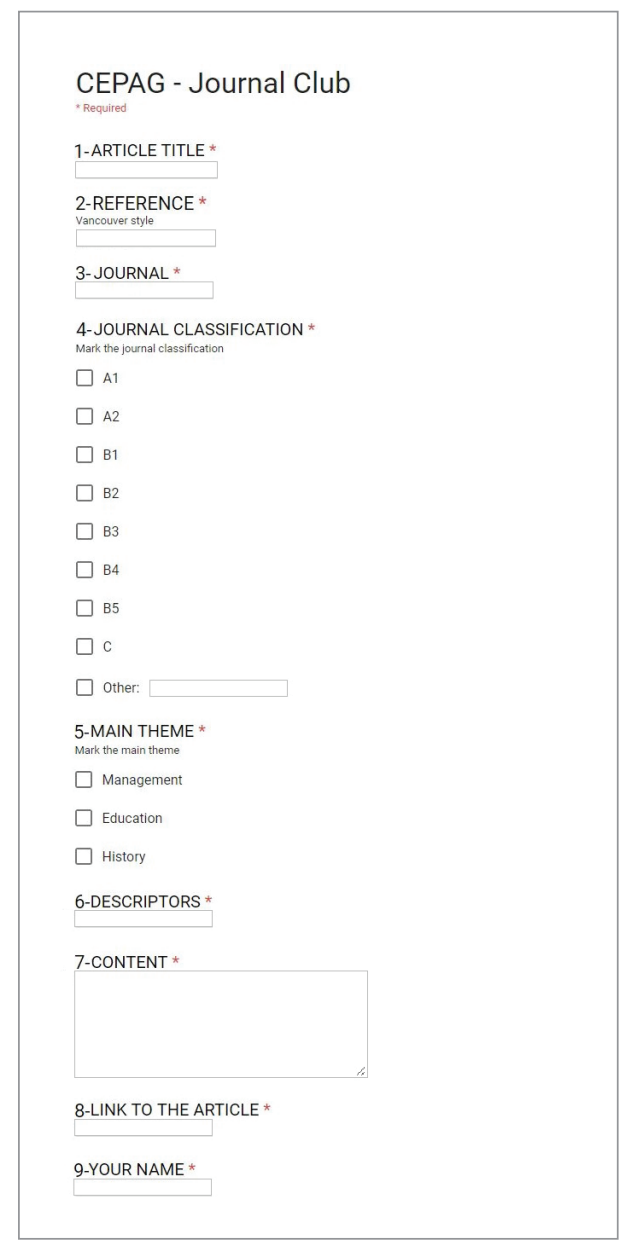

Figure 2 - Release Form of information about articles from Journals Club

Thus, it was possible to optimize Gepag's time of meetings, facilitating the access of its members' publications of interest to the Group and creating a database to support future studies of these researchers.

The initiative was supported by the members of the group, who were able to spend more time of the monthly face-to-face meeting to the discussion of projects and research results of the group itself.

The base created is cumulative, that is, nothing is excluded from the records made concerning time or any other criteria, and its consultation facilitates the preparation of projects and research reports in Gepag development.

1 Qualis is a Brazilian assessment for academic Journals. 
Chart 1 - Journals that were part of the Club, September 2016

\begin{tabular}{|c|c|c|}
\hline Journal & Abbreviation & Periodicity \\
\hline ACTA Paulista of Nursing & Acta Paul Nurse & Bimonthly \\
\hline Ciência y en Enfermería & Ciencia y Enferm & Quarterly \\
\hline Cogitare Nursing & Cogitare nurses. & Quarterly \\
\hline Anna Nery school journal of nursing & School Anna Nery & Quarterly \\
\hline History of Nursing: electronic magazine & HERE & Semi-annual \\
\hline Interface communication, health, education & Interface (Botucatu) & Quarterly \\
\hline Journal of Nursing and Health & JONAH & Semi-annual \\
\hline Journal of Nursing Management & J Nurs Manag & Monthly \\
\hline Online Brazilian Journal of Nursing & OBJN & Quarterly \\
\hline Brazilian Journal of Nursing & Rev Bras Enferm & Bimonthly \\
\hline Journal of the nursing school from USP & Rev Esc Enferm USP & Bimonthly \\
\hline Nursing Network Journal of the Northeast & Rev Rene & Bimonthly \\
\hline Health Administration journal & RAS & Quarterly \\
\hline Research Journal: Care is Fundamental Online & REPEF & Quarterly \\
\hline Nursing Electronic journal Global & Global Nursing & Semi-annual \\
\hline Electronic journal of nursing (REE) & REE & Quarterly \\
\hline Nursing in Focus journal & Focus Nursing & Quarterly \\
\hline Nursing Journal UERJ & Rev. nurses. UERJ & Bimonthly \\
\hline Gaucho nursing journal & RGE & Quarterly \\
\hline Latin American Journal of nursing & RLAE & Bimonthly \\
\hline Mineira Nursing journal & REME & Quarterly \\
\hline Nursing journal & Nursing & Monthly \\
\hline Work, education and health journal & Work, education and health & Quarterly \\
\hline Text \& Nursing Context & Text Context Nurse & Quarterly \\
\hline
\end{tabular}

\section{FINAL CONSIDERATIONS}

The JC is an efficient strategy for updating the participating researcher of the research groups. The computer resource usage allowed to optimize the time of meetings, without access impairment to the selection and review of published studies according to members' interest of the Gepag, that help its members stay up-to-date and to inform about the State of the production of knowledge in the line of research in that Act.

With this activity, the PhD candidates also could develop their skills, and they like the other members of the Group were encouraged to the critical reading of publications and practice discussion about the methods employed by other researchers and on the findings of researches developed in equivalent topics or similar to those practiced in the group.

Despite this, there are limitations regarding the use of the instrument described in this report as to the correct, complete and frequent filling of data, which must be provided by the research group that wishes to replicate its use. It is therefore suggested that this task be incorporated into the competency development plan adopted by the group and to constantly monitor its execution. It should be noted, however, that although these difficulties exist, this type of activity strengthens the growth of the group and facilitates its organization, that is why the strategy was presented, hoping that the groups that may experience it can point the results of its use for the instrument improvement. 


\section{REFERENCES}

1. Brasil. Ministério da Ciência e Tecnologia. Conselho Nacional de Desenvolvimento Científico e Tecnológico (CNPq). Diretório dos Grupos de Pesquisa no Brasil [Internet]. Brasília (DF), 2014[cited 2016 Apr 4]. Available from: http://dgp.cnpq.br/dgp/ espelhogrupo/0507469784433165

2. Universidade Federal de São Paulo. Escola Paulista de Enfermagem. Grupos de Pesquisa [Internet]. São Paulo (SP), 2016[cited 2016 Jul 5]. Available from: http://www.unifesp.br/campus/sao/epe4/sobre-a-epe/departamentos/dasc/missao-visao-e-valores-3

3. Silva MRG, Sanna MC. Projetos de pesquisa propostos pelo Grupo de Administração da Escola Paulista de Enfermagem. Nursing (São Paulo) [Internet]. 2016 [cited 2016 Apr 4];18(218):1096-102. Available from: http://pesquisa.bvsalud.org/aleitamentomaterno/ resource/pt/bde-28197

4. Harris J, Kearley K, Heneghan C, Meats E, Roberts N, Perera R, Kearley-Shiers K. Are journal clubs effective in supporting evidencebased decision making? a systematic review. BEME Guide No. 16. Med Teach [Internet]. 2011[cited 2016 Jul 26];33(1):9-23. Available from: http://dx.doi.org/10.3109/0142159X.2011.530321

5. Shifflette V, Mitchell C, Mangram A, Dunn E. Current approaches to journal club by general surgery programs within the Southwestern surgical congress. J Surg Educ [Internet]. 2012 [cited 2016 Apr 4];69(2):162-6. Available from: http://www.jsurged. org/article/S1931-7204(11)00244-3/pdf

6. Wilson M, Ice S, Nakashima CY, Cox LA, Morse EC, Philip G, et al. Striving for evidencebased practice innovations through a hybrid model journal club: a pilot study. Nurse Educ Today[Internet]. 2015 [cited 2016 Apr 4];35(5):657-62. Available from: http:// www.nurseeducationtoday.com/article/S0260-6917(15)00081-7/fulltext

7. Westlake C, Albert NM, Rice KL, Bautista C, Close J, Foster J, et al. Nursing journal clubs and the clinical nurse specialist. Clin Nurse Spec [Internet]. 2015 [cited 2016 Apr 4];29(1):E1-E10. Available from: https://www.ncbi.nlm.nih.gov/pubmed/25469443

8. Scherzer R, Shaffer K, Maceyko K, Webb J. Journal Club for Prelicensure Nursing Students. Nurse Educ [Internet]. 2015 [cited 201606 30];40(5):224-6. Available from: https://www.ncbi.nlm.nih.gov/pubmed/25888102

9. Friedländer MR, Arbués-Moreira MT. Análise de um trabalho científico: um exercício. Rev Bras Enferm [Internet]. 2007 [cited 2016 Jul 26];60(5):573-8. Available from: http://www.scielo.br/pdf/reben/v60n5/v60n5a17.pdf

10. Lima DVM. Research design: a contribution to the author. Online Braz J Nurs [Internet]. 2011 [cited 2016 Apr 4];10(2). Available from: http://dx.doi.org/10.5935/1676-4285.20113648

11. Google. O que é Google Drive e como usar [Internet]. 2012 [cited 2017 Apr 7]. Available from: http://www.techtudo.com.br/ artigos/noticia/2012/04/o-que-e-google-drive-e-como-usar.html 